DOI https://doi.org/10.18551/rjoas.2017-07.13

\title{
PROBLEM IDENTIFICATION OF FOREIGN TOURIST DISTRIBUTION IN INDONESIA
}

\author{
Supriono*, Topowijono, Mochammad Al Musadieq \\ Faculty of Administrative Science, University of Brawijaya, Indonesia \\ *E-mail: supriono fia@ub.ac.id
}

\begin{abstract}
Indonesia should be able to distribute evenly the visits of foreign tourists so that the visit is not merely focused on certain places. It is expected that all the tourism objects in Indonesia can attract and be visited by foreign tourists with the same quantity or number in every tourist destination. In the first year, this study aimed to identify the motivation of foreign tourists visiting Indonesia and identify the problems of distribution of foreign tourists in Indonesia. The study sites were in DKI Jakarta, Batam, and Bali. In the second year later, a distribution channel strategy will be developed in order to create competiveness of tourism. This study was conducted using qualitative research methods with descriptive analysis. The data were collected using in-depth interviews with tourism stakeholders (the Government, International Travelers, and Tourism Bureau/Travel Agencies). The research results show that the motivation of foreign tourists visiting Indonesia was related to business and purely on vacation. Additionally, the problems of foreign tourist distribution in Indonesia emerged because of some aspects, including limited entrance of foreign tourists to Indonesia, lack of connectivity between airports in Indonesia and international flights, lack of inter-regional cooperation between tourism actors, lack of infrastructure, and the ignorance of foreign tourists to all tourist destinations in Indonesia due to less effective and efficient promotion activities.
\end{abstract}

\section{KEY WORDS}

Tourism, distribution, foreign tourist, destinations.

Tourism is very meaningful for Indonesia because it is one of the state revenue sources of foreign exchange (Subiyantoro and Andreani, 2003). These conditions illustrate how potential the tourism of Indonesia in the future to increase the contribution of foreign exchange to the State of Indonesia. Unfortunately, these conditions occur only in certain places in Indonesia. According to the Ministry of Tourism and Creative Economy, the visits of foreign tourists were only focused on Bali $(40 \%)$, Jakarta (30\%), and Batam (25\%) (Koran Sindo, March 23, 2015). The absence of a good distribution channel will affect the development of Indonesian tourism.

A good distribution channel is a channel that is able to distribute evenly foreign tourists to every tourism destination in Indonesia although it is located in remote areas. An appropriate distribution channel in tourism activities refers to an equal distribution of tourist arrivals in every region in Indonesia. This condition will also result in equal income distribution of the society who is engaged in the field of tourism. In addition, the increasing number of tourist visits will result in the competitiveness of Indonesian tourism, compared to other countries.

\section{THEORETICAL REVIEW}

Tourism. Tourism is an activity of human movement in groups or individually from one place to another for social, cultural, economic, politics, religion, health purposes and so on (Suwantoro, 2002). Meanwhile, according to WTO (1999), tourism is a human activity of leaving the daily environment to carry out temporary traveling. In essence, tourism activity is a human activity to migrate or move from one place to another for a while in order to do certain purposes, either for fun or for other businesses. 
Distribution Channels. According to Gregory et al. (2005), distribution channels are formed to facilitate the exchange process between producers and consumers. Meanwhile, the meaning of the exchange is the activity of sale/purchase and shipping transactions between producers and consumers. A distribution channel is a structure that describes the channel alternatives chosen by each business and the different marketing situations by various business activities.

Tourism Distribution Channel. The distribution function in tourism is somewhat different from the distribution of goods in general. The prominent differences among which are discussed in the following section.

Tourism products consist of many elements, each of which is a different company product such as transportation, accommodation, bar and restaurant, entertainment, sightseeing tour, tourist object, and so on. Tourists usually consume it in a form of "package" and they are rare to consume it separately. This kind of product cannot be wrapped to be delivered or shipped to consumers. It also cannot be stacked for future purposes. Therefore, the issues of warehousing, transportation, and supplies do not matter in this case.

In concrete goods, if the goods are required by the consumers, then the goods can be sent by an intermediary (middleman) to where the goods are needed. In contrast, tourism products can be enjoyed or consumed by tourists (consumers) if the tourists make a movement by themselves. In other words, Travel Agents or Tour Operators are the only distributor institutions who have to arrange the tourists' trips to the desired destinations. By this way, the products of tourism industries can be consumed by tourists. This is also because the services provided cannot be separated from the producers/agents who make it.

Conversely, creating complementarily products is a task that is highly important to be conducted by distribution agencies in the tourism business. As an example, a travel agent can organize or prepare transportation to the destination area, make a hotel reservation, and arrange sightseeing tour in the place to be visited. This is what we call as "assortment of services". Similarly, tour operators can also plan and organize tours in accordance with the combination of objects and attractions desired by tourists.

\section{DISCUSSION OF RESULTS}

Analysis of Foreign Tourist Distribution Channels in Indonesia. In Indonesia, there is no equalization or even distribution of foreign tourists in all destinations of each region. This is indicated by the gathering of foreign tourists at several points of entrance, including Bali, Jakarta, and Batam. Thus, there is an assumption that the other regions in Indonesia cannot contribute much to the tourism development although the fact does not proceed that way. The ineffectiveness of the distribution channel is one causing the condition occurs.

Based on the results of the study, it turns out that there are many problems leading the tourists to choose the entrance of the three regions.

Visit Motivation of Foreign Tourists. The foreign tourist visits or arrivals in Indonesia are not only for having fun. Each of them has their own reasons or purposes. Moreover, every visiting tourist commonly has made visit plans regarding the destination places or regions. The interests or purposes of tourist visits include making business, attending conferences/meetings, traveling for a spiritual journey, and taking a vacation.

Based on the motivation of foreign visitors mentioned above, it can be ensured that such conditions make the areas that do not have much potential of tourism get only a little number of foreign tourists or visitors. Jakarta for example, the majority of Jakarta's foreign tourist arrivals or visits are motivated by business purposes such as attending conference/meeting. This is reasonable because Jakarta is the capital of Indonesia, and most of the central offices are located there. It is very unlikely that foreign tourists come to Jakarta for vacation/holiday since the condition does not support. In addition to its traffic, Jakarta is also less able to provide a natural tourist destination. If any, it must be outside the urban areas and it takes a long time to reach it.

Thus, it can be concluded that Jakarta more develops MICE tourism destinations (Meeting, Incentives, Convention, and Exhibition). The availability of facilities for such 
activities is at least able to facilitate the tourist motivation to visit there. The great number of hotels and ballrooms used for meetings has proved this.

Unlike Jakarta, the majority of foreign tourists coming to Bali are motivated by vacation purpose. They focus on having fun. Even if it is a kind of business affair, that is not the main purpose or motivation of their visits (relatively small). Therefore, many tourists prefer natural places, which are safe, away from the atmosphere of noisy, and completed with good tourism infrastructures.

Bali provides a lot of tourist destinations that are desired by and interesting for the foreign tourists who are purely on vacation. They usually will feel at home when staying in Bali and tend not to move to another place because they can get everything they want there. Such a condition can happen because Bali is indeed more focused on its tourism activities that are entertaining. The provision of infrastructures in Bali that is better than other regions in Indonesia has made foreign tourists more tend to choose Bali compared to other areas/regions of vacation.

The various motivations of foreign tourists have made the distribution of their visits become not even or equal in each region/area in Indonesia. To attract foreign tourists coming to a certain region, there should be good destinations that can make them desired or interested. Thus, every region must have its own peculiarities that will likely attract foreign tourists to visit.

In general, the regions in Indonesia are less able to develop their potentials as tourism destinations. There is a tendency to imitate the well-known and eminent tourist destinations of other regions, even if the concepts are made exactly the same but with a different name. For example, the development of Jember Fashion Carnival (JFC) has been imitated or followed by many other regions in Indonesia in which the concept is the same.

Furthermore, sometimes each region has a concept that competes with other regions. If there is a certain tourism destination in one region, then the other regions should also make a destination with the same concept. For instance, if, in a region, there is a touristtraditional attraction or dance called 'reog', the other regions will also develop or imitate the concept of that 'reog'.

Such conditions lead tourist destinations in Indonesia to be not getting richer or improved; instead, it will be more homogeneous. Foreign tourists tend to be easily bored because they have seen the same tourist attractions in some regions. This is because the tendency of foreign tourists to visit a region is to know and feel a new experience that is different from before. If they are presented with the same thing/attraction, it will waste their time. Moreover, when they get bored with the tourist destinations that they have experienced, there is a possibility that they will not recommend his friends to visit somewhere in Indonesia after returning to his country.

Limited Entrance for Foreign Tourists Coming to Indonesia. The national entrance or gateway of Indonesia for foreign tourists who want to visit is categorized limited. The bestknown ones include Bali through I Gusti Ngurah Rai Airport, Jakarta through Soekarno Hatta Airport, as well as Batam through Hang Nadim Airport and Batam Center Port. It is lacking for Indonesia to have only these three regions to be visited by foreign tourists, considering Indonesia has a vast territory unfolding from Sabang to Merauke.

National entrance or gateway is very influential on the visit of foreign tourists to Indonesia. The fact is that the majority of the visit of foreign tourists to Indonesia must first pass through the 3 (three) gates although their main destinations are not necessarily to those three regions. Eventually, whether or not they want it, they have to pass through those regions.

Actually, there are also other entrances or gateways to Indonesia, such as Juanda Airport (Sidoarjo), Hasanudin Airport (Makassar), Lombok International Airport (Praya), Kualanamu Airport (Medan), and so on. However, most of those gates are not familiar among foreign tourists who want to visit Indonesia.

With such conditions, every tourist will spend a lot of money to reach the destinations that they want to visit. As an example, the foreign tourists who want to visit Bunaken Park 
must pass through Jakarta first to transit for then going to the Park. It also happens for foreign tourists who want to visit Toba Lake, Raja Ampat, Toraja, etc.

It is not a problem if it happens to foreign tourists who derive from countries in the Asian continent because of its relatively near location to Indonesia. But, it becomes a problem when the foreign tourists visiting Indonesia come from the European or American continent because it certainly will take a longer time on the journey to just transit.

Indonesia does need to develop, expand, and multiply the entrance or gateway for foreign tourist visits. This is because the distance between the regions relatively need very long time to reach. If the national entrance is only focused on the three regions, it is unlikely that many foreign tourists would like to visit the other areas or regions in Indonesia, unless they have a lot of money and time.

It is indeed that Soekarno Hatta Airport of Jakarta provides a variety of flights to any other regions in Indonesia although the distance that must be taken can be very long because the regions are not located right in the middle of the territory of Indonesia. The airport may only be able to reach the western part of Indonesia because the travels only take a maximum of 2 hours. Nevertheless, it does not apply to the eastern regions in which its average distance from Jakarta is over 4 hours and it requires a relatively expensive cost.

The main entrance or gateway for foreign tourists coming to Indonesia for this time is Soekarno Hatta Airport. However, the fact says that the great number of foreign tourist visits or arrivals in Jakarta is not in line with the number of foreign tourist visits in the tourist destinations of Jakarta. In Soekarno Hatta Airport, it is reported that the total foreign tourist arrivals are 2,455,279 people (Directorate General of Immigration, 2016), and, in the same year, the total number of foreign tourist visits in the tourism destinations of Jakarta is only 95,701 people (Central Bureau Statistics of Jakarta, 2016). Thus, it can be concluded that the purpose of the majority of foreign tourists arriving and passing through Soekarno Hatta Airport is only for transit.

Lack of Tourism Network between Regions. Inter-regional tourism network in Indonesia can be categorized minimal or limited and it tends to be focused on regionalism. This will greatly affect the visits of foreign tourists from one region/area to another, considering that foreign tourists will not visit the unwell-known places or regions.

Based on the interviews with some tourism stakeholders in Bali (travel agencies, innkeepers, restaurants, etc.) as the most frequently visited place by foreign tourists, the majority of foreign tourists said that they never served tour packages to areas other than Bali, even never recommend to the areas outside Bali. Even if ever, they would only refer to the areas that are still close enough to Bali, such as Lombok or Flores (Komodo Island)

Lack of communication is the main factor causing a passiveness or ignorance of the development of other tourist destinations. Many of tourism actors are satisfied and overwhelmed to serve tour packages in their own respective areas, especially in Bali, Jakarta, and Batam. Therefore, most foreign tourists tend to visit or gather in those three regions. They rarely visit other destinations in Indonesia. This is not because they do not want to, but they have less information or knowledge related to the existence of tourist destinations other than the three regions.

Such a condition is still coupled with a situation of competition such as awarding for best regional tourism destination at the national level. Actually, this event has a good purpose, that is to encourage the tourism actors to develop the regional tourism and they can finally learn a lot from the best tourism-awarded regions. However, the negative impact that can arise is an unhealthy/unfair competition in which there is a tendency to consider other areas/regions as competitors, not as the partners in tourism activities.

If the government wants to have a progress in the field of tourism in Indonesia, the actors of tourism should establish a relationship that is not focused only on each region. They should make their tourism as a global attraction on behalf of Indonesia. There is no need to compete because each region in Indonesia must have a diversity and has their own characteristic that cannot be owned or imitated by other regions.

Building cooperation is an appropriate solution that may be applied if the local government or tourism actors want to get inter-regional foreign tourist visits. The cooperation 
can be in the form of sharing information (particularly between the foreign tourists-crowded regions and the less crowded ones). Travel agents can also carry out a cooperation in the field of providing inter-regional tour packages.

The existence of this cooperation will also increase the benefits of tourism actors. The tourism actors can mutually manage foreign tourists coming from one region and give them recommendations to visit tourist destinations in other regions.

The purpose of such cooperation is to extend the distribution channels of tourism and to involve many parties (e.g. the parties of travel agents in region $A$ and region $B$ ). In other words, the number of parties who get involved in tourism activities is increasing. Thus, the existence of integrated inter-regional tourism activities in Indonesia will benefit many parties because the foreign visits are evenly distributed in each region.

Less Effective Promotion Activities. Based on the answers given by the foreign tourists of this study regarding the existence of tourist destinations in Indonesia, it is found that the majority of foreign tourists did not much know about Indonesian tourism. What they only knew were limited to Bali, Jogjakarta, Jakarta, and Batam. Furthermore, when they were asked about whether they wanted to visit tourist destinations in other regions in Indonesia, they answered hesitantly.

The promotion activities of Indonesian tourism are considered less effective for foreign tourists. Foreign tourists mostly get information of Indonesia tourism from the internet, not from promotional activities that are often held by the Government and travel agencies. This indicates that the promotion activities that have been held are not right on the target.

Based on the data of travel agents, the promotion activities that was commonly conducted was by establishing cooperation between Indonesian travel agents and international/foreign travel agents. However, such promotion activity is considered less effective since not all foreign tourists visiting Indonesia use the services of travel agents. Many of them actually make visits independently or are invited by their Indonesian friends or business partners.

According to foreign tourists, the most effective way to do promotion is through internet network. It has been a custom or tendency that every foreign tourist who is going to visit a country will certainly seek information related to the country via the internet. Once they get adequate information on the country, they are just leaving to visit it.

Furthermore, the security is one of the factors that often make the tourists become hesitant to visit an area or region in Indonesia. Foreign tourists in Bali often spend their holiday time for days, even months because they feel safe there. This is because the promotion of Bali tourism has ensured that the people of Bali will guarantee the security of every tourist visiting there.

Other areas or regions in Indonesia have not been able to promote and guarantee the security of foreign tourists as good as Bali. Because, in addition to having fun, foreign tourists must want that their safety will be guaranteed. This has also made the foreign tourist distribution in Indonesia often experience obstacles.

\section{CONCLUSION AND SUGGESTIONS}

Based on the explanation of the research results above, the conclusions obtained from the three tourist destination areas in Indonesia are as follows:

The motivation of foreign tourists to visit Indonesia is varying. The majority of foreign tourists arriving in Jakarta are for business purpose and transit, and the majority of foreign tourists visiting Batam are only for business purpose. Meanwhile, the majority of foreign tourists visiting Bali are for having fun or on vacation.

The problems of foreign tourist distribution in Indonesia include:

Limited entrance or gateway for foreign tourists coming to Indonesia. Indonesia only has several gates for the entrance of foreign tourists. The most crowded ones are Jakarta, Bali, and Batam. In fact, it cannot be ensured that their main arrivals or destinations are to the three areas, but to other areas. For instance, a foreign tourist goes down Jakarta and he then continues his trip to Bandung. Another example, a foreign tourist arrives first in Bali, but 
then he makes a transit to visit Lombok and Flores. This can happen because there is a lack of direct connectivity between Indonesian airports and foreign airports.

Lack of inter-regional cooperation network of stakeholders in Indonesia. Each region has their own ego or business.

Less effective and efficient promotion activities conducted by the government or other tourism actors. This is proved by a contradiction in which the government and travel agents have carried out promotion activities but the reality says that majority of foreign tourists claim to not know the areas of destinations in Indonesia wholly. The only places they know are Jakarta, Bali, Yogyakarta, Lombok, and Flores (Komodo).

From the research, several suggestions can be made as follows.

Indonesia should further develop its tourist destinations in a balanced way because the motivation of foreign tourists coming to Indonesia is not only for vacation or having fun but also for other purposes such as business establishment and spiritual journey. In term of business purpose, MICE destination can be developed as tourism object. In term of religion or spiritual purpose, the development of tourist destinations can be in the form of providing good infrastructure facilities in each religious place such as Walisongo tomb, Borobudur temple, Cathedral church, and so on.

The entrance or gateway for foreign tourists coming to Indonesia should be expanded or multiplied right on the target of tourist destinations, without having to transit to a certain place.

An integrated cooperation network among tourism stakeholders must be developed from one region to another.

The promotion activities should be done in integration and right on target, as well as focused on the potential tourists. Furthermore, it will be better to make promotion via the internet.

\section{REFERENCES}

1. Gartner, W.C. and Bachri, T. (1994). Tour operators' role in the tourism distribution system: an Indonesian case study. Journal of International Consumer Marketing, Vol. 6 No. $3 / 4$,

2. Gundlach, Gregory, (2005). The Structure of Commitment in Exchange. Journal Marketing, Vol 59 (January). Pp 78-92. pp. 161-79.

3. Griffin \& Ebert, R.J. (1996). Bisnis: Buku Satu. Jakarta.

4. Kotler, P. \& G, Armstrong. (2001). Prinsip-Prinsip Pemasaran. Translated by D. Sihombing. Jakarta: Erlangga.

5. Lubis, N.A. (2004). Peranan Saluran Distribusi Dalam Pemasaran Produk dan Jasa, Fakultas Ekonomi Jurusan Manajemen, Research Report, Universitas Sumatera Utara. Medan.

6. Lupiyoadi, R. \& Hamdani, A. (2006). Manajemen Pemasaran Jasa. Jakarta: Salemba Empat.

7. Setiawan, I. (2015). Potensi Destinasi Wisata di Indonesia Menuju Kemandirian Ekonomi. Proceeding. ISBN: 978-979-3649-81-8. UPI. Bandung.

8. Stanton, W.J. and Walker, B.J. (1991). Fundamentals of Marketing. NY: McGraw-Hill.

9. Subiyantoro, E. \& Andreani, F. 2003. Analisis Faktor-Faktor Yang Mempengaruhi Harga Saham (Kasus Perusahaan Jasa Perhotelan yang Terdaftar di Pasar Modal Indonesia). Jurnal Manajemen \& Kewirausahaan, Vol. 5, No. 2, September 2003: 171 - 180

10. Suwantoro, G. (2002). Dasar-Dasar Pariwisata. Yogyakarta: Andi Offset.

11. Yoety, A.O. 2008. Ekonomi Pariwisata: Introduksi, Informasi, dan Aplikasi. Kompas. Jakarta 